THE INTERNATIONAL

REVIEW OF RESEARCH IN

OPEN AND DISTANCE LEARNING

\title{
Examining Interactivity in Synchronous Virtual Classrooms
}
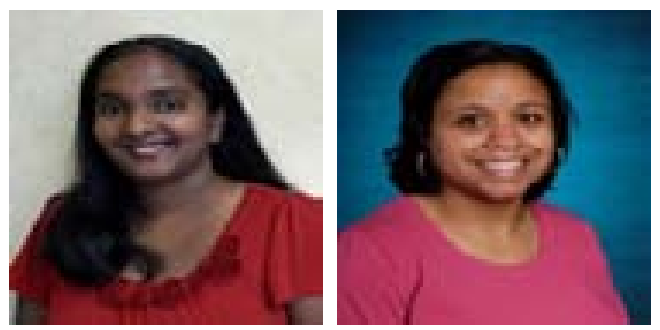

Florence Martin, Michele A. Parker, and Deborah F. Deale University of North Carolina Wilmington, USA

\section{Abstract}

Interaction is crucial to student satisfaction in online courses. Adding synchronous components (virtual classroom technologies) to online courses can facilitate interaction. In this study, interaction within a synchronous virtual classroom was investigated by surveying 21 graduate students in an instructional technology program in the southeastern United States. The students were asked about learner-learner, learner-instructor, learner-content, and learner-interface interactions. During an interview, the instructor was asked about strategies to promote these different forms of interaction. In addition, the academic, social, and technical aspects of interactions were examined in three course archives using Schullo's (2005) schema. Participants reported that the Wimba interface was easy to use and that various features, such as text chat and the webcam, facilitated interaction among the students and with the instructor in the virtual classroom. The importance of students' ability to receive immediate feedback and their experience as presenters was highlighted across the various kinds of interaction. The instructor's teaching style and visual presence were instrumental in engaging students with the content. The results suggest that student interaction, and hence learning, was aided by the live communication that occurred through the virtual classroom. This study has implications for those who are considering adopting virtual classroom technologies for their online or blended teaching.

Keywords: Synchronous, virtual classroom; learner-learner; learner-instructor; learnercontent; learner-interface; interaction 


\section{Introduction}

Sloan Consortium reports that over 6.1 million students were enrolled in at least one online course in the fall of 2010 (Allen \& Seaman, 2011). Online instruction is rapidly gaining acceptance as an alternative and a supplement to traditional classroom instruction (Arbaugh, 2000). According to Coleman (2012), students enroll in online courses for a variety of reasons, which include anywhere/anytime learning, increased student interaction, acquiring skills in using technology, and instructors being more approachable. Asynchronous online courses offer anytime/anywhere learning to the students; whereas, in synchronous online courses, students have the freedom of place but have to login at a specific time. Studies have shown that students succeed in online courses when they are active participants (Verneil \& Berge, 2000), and therefore interaction is crucial to student satisfaction and engagement in online courses (Mandernach, 2005).

Kearsley (1995) states that a high level of interaction is desirable and enhances the effectiveness of any distance education course. This need for interaction has resulted in the development of guidelines for designing effective online courses (Roblyer \& Ekhaml, 2000). While asynchronous courses provide interaction primarily through discussion forums, synchronous courses provide real-time interactions. Adding synchronous components to online courses can enrich meaningful interactions (Repman, Zinskie, \& Carlson, 2005). Virtual classroom technologies are a cost-effective method for synchronous delivery in online courses, which were initially made possible through video conferencing technologies.

\section{Synchronous Virtual Classrooms}

Virtual classrooms allow instructors and students to interact online synchronously. The best advantages of synchronous online instruction are that faculty and students can talk to each other using text, audio, and video and express emotion using emoticons. Synchronous virtual classrooms provide the instructors with the ability to poll students instantly and afford the students the chance to participate in group activities in the breakout rooms, while having the feeling that they can still interact as if they were face-to-face (Wimba, 2011). These interactive elements are unavailable in an asynchronous course.

The features available in the synchronous virtual classroom play an important role in maintaining interaction. Most of the virtual classroom technologies have a content frame to share the instructor's PowerPoints, an eboard where an instructor can write, breakout rooms for group activities, text chat so the instructor and other students in the class can interact using words and emoticons, and audio chat to talk via microphone or telephone with the instructor and other students. Instructors can administer student polls, share their desktop, or have the students share their own desktops through application sharing. Web sites can be displayed for students, and with a stable Internet bandwidth webcams can be used so students and instructors can see each other. Some of the common virtual classrooms available in the market today are Elluminate, Adobe Connect, Webex, and Horizon Wimba.

Cao, Griffin, and Bai (2009) suggest that synchronous interaction effectively increases student satisfaction. Synchronous tools are also helpful in the social aspects of education (Mot- 
teram, 2001). Park and Bonk (2007) list the major benefits of using a synchronous virtual classroom as follows: providing immediate feedback, encouraging the exchange of multiple perspectives, enhancing dynamic interactions among participants, strengthening social presence, fostering the exchange of emotional supports, and supplying verbal elements. When comparing asynchronous and synchronous interaction, Chou (2002) found that there were more socioemotional interactions in the synchronous communication mode, which enhanced interpersonal connections. Chou also found that there was more one-way communication in the asynchronous mode as students seemed to be more interested in expressing opinions than challenging each other's views; whereas, in synchronous mode, there were more questions and answers. Students were more engaged in the synchronous discussions.

\section{Defining Interaction}

Early definitions of interaction were considered human-to-human, where two people were involved. Daniel and Marquis (1988) defined interaction as activity in which a student is in two-way contact with one or more persons. Later, Gilbert and Moore (1998) defined interactivity in computer-mediated instruction as the reciprocal exchange between the technology and the learner. Wagner (1994) differentiates between interaction and interactivity. Wagner suggests that "interaction functions as an attribute of effective instruction while interactivity functions as an attribute of instructional delivery systems" (p. 6). She further defines instructional interaction as "an event that takes place between a learner and learner's environment and its purpose is to respond to the learner in a way intended to change his or her behavior toward an educational goal" (p. 9). In this study, we accept Wagner's differentiation of interactivity as a machine attribute and interaction as an outcome of using interactive instructional delivery systems. However, we agree with Roblyer and Ekhaml (2000), who state that there is also a relationship between these two terms in online courses. Technologies that are considered highly interactive permit learner-learner, learner-group, and learner-system interaction, which occurs in synchronous virtual classrooms. Thurmond and Wambach (2004) describe interaction in distance education as "the learner's engagement with the course content, other learners, the instructor, and the technological medium used in the course" (p. 4). This description best explains interaction in the synchronous virtual classroom.

\section{Types of Interaction}

Moore (1993) identified three types of interaction inherent in effective online courses: 1) learner-to-content interaction, 2) learner-to-instructor interaction, and 3) learner-tolearner interaction. Learner-content interaction is the process of intellectually interacting with the content, which changes the understanding, perspectives, and cognitive structures of a learner's mind. Learner-instructor interaction is highly desirable as the instructor seeks to stimulate, or at least maintain, student interest in what is to be taught and to motivate the student to learn. Learner-learner interaction is an extremely valuable resource for learning, and Moore (1993) emphasized the importance of students' interaction with their peers in his work. 
Hillman, Willis, and Gunawardena (1994) introduce a fourth type of interaction, interaction with technologies. They present the concept of learner-interface interaction and recommend instructional design strategies that will facilitate students' acquisition of the skills needed to participate effectively in the online classroom. Hillman et al. (1994) define learner-interface interaction as "a process of manipulating tools to accomplish a task" (p. 34). The learner must understand not only the procedures of working with the interface but also why these procedures obtain results. Later, Anderson and Garrison (1998) introduced three other types of interaction: teacher-teacher, teacher-content, and content-content. They suggest that teacher-teacher interaction usually occurs in the context of professional development, where teachers interact with each other to develop their teaching competencies. Teacher-content interaction is considered essential and is the form of interaction expected from most teachers in higher education. However, Anderson and Garrison question whether this occurs while using computer technologies that combine content and communication. Content-content interaction is made possible by the use of intelligent agents, who search for updated content information. Not all types of interaction have educational value. Anderson (2003) concludes that "deep and meaningful formal learning is supported as long as one of the three forms of interaction (student-teacher; student-student; studentcontent) is at a high level" (p. 4). Having one or more of the three interaction types at a high level results in a satisfying educational experience.

\section{Interaction Framework}

Ally (2004) proposes a framework of lower level to higher level interactions based on behaviorist, cognitivist, and constructivist schools of learning (see Figure 1). The learner-interface interaction is considered the lowest level of interaction and is represented at the top of the flowchart. This learner-interface interaction allows the learner to access the information, and it is here that the learners use their senses to register the information in sensory storage. The learner-content interaction is the next level in the flowchart. This is where learners navigate through the content to access the various components of the lesson. In this interaction, the learners process the information to transform it from short-term to long-term memory. The higher the level of processing, the more associations that are made in long-term memory, which results in higher-level learning. As the flowchart progresses and as the learners work through the content, the type of learner support needed can change (e.g., learner-learner, learner-instructor, and learner-expert). Finally, at the highest level is the learner-context interaction, which allows learners to apply what they learn in real life so that they can contextualize the information. 


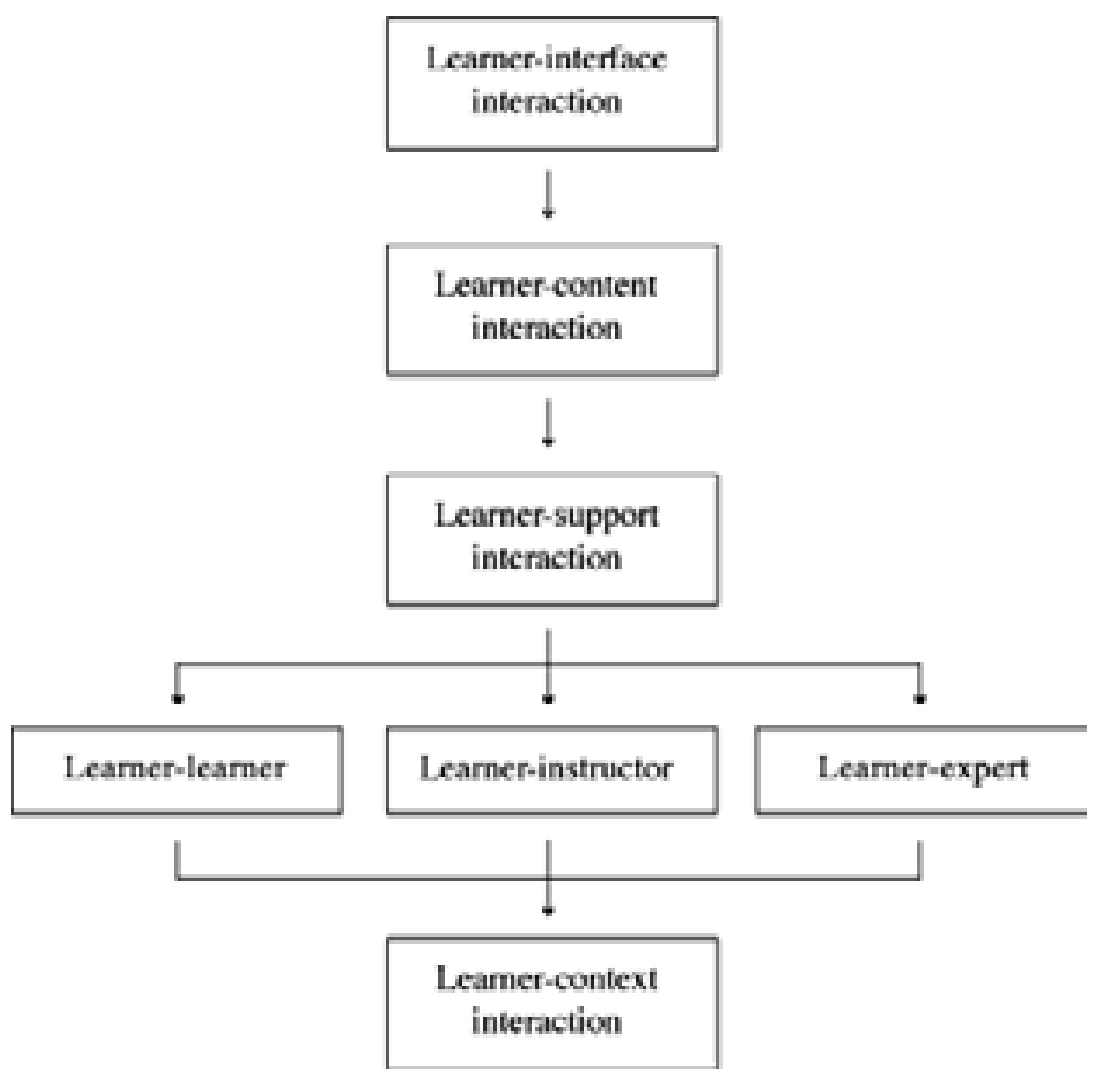

Figure 1. Ally's levels of interaction in online learning (Theory and Practice of Online Learning, 2004, p. 21). Reprinted with permission.

\section{Interaction in Online Courses}

Traditionally, interaction focused on dialogue between students and teachers in the classroom (Anderson, 2003). This concept has expanded to include synchronous online discussions (text, audio, and video chat) and asynchronous online discussions (discussion forums, text, and voice mail). Kearsley (1998) indicates that interaction among participants is the most important requirement for successful online education. Frequency and quality of interaction between student and lecturer determines the effect of instruction (Pittinsky \& Chase, 2000). Gilbert and Moore (1998) note that social rapport and increased collaboration lead to greater levels of interaction. Martyn (2005) suggests that successfully fostering interaction in online courses requires incorporating both instructional and social types of interaction. Effectively designed courses should impact students in such a way that there is an increased and spontaneous use of opportunities for interaction within the courses.

Some studies have found no significant differences in assessing interaction between students in a synchronous and asynchronous course (Miller \& Webster, 1997). On the other hand, several studies have found that well-designed courses can be more interactive than others (Hirumi \& Bermudez, 1996). Roblyer and Ekhaml (2000) designed a four-dimensional rubric that helps to score the interactivity of distance education based on four criteria: 1) social goals of interaction, 2) instructional goals of interaction, 3) types and uses of technologies, and 4) impact of interactive qualities as reflected in learner response. Northrup 
(2001) proposed five different purposes for interaction: to interact with content, to collaborate, to converse, to help monitor and regulate learning, and to support performance.

The researchers reviewed the extant literature on interaction and synchronous systems. The appendix provides details of eight current studies. McBrien and Jones (2009) found that dialogue, structure, and learner autonomy enhanced learner interaction in a synchronous online setting. Meanwhile, LaPointe and Gunawardena (2004) stated that computermediated conferencing experience had a moderate direct effect on self-reported peer interaction and had a strong direct effect on self-reported learning outcomes. Aydin (2008) recommended that an e-class (a synchronous virtual classroom) might increase interaction among students because such an application motivates learners and encourages them to develop positive attitudes towards the course. Wang (2004) supported the use of video conferencing in distance learning for the provision of oral-visual interaction. Abdous and Yen (2010) found that delivery mode (face-to-face, satellite broadcast, and live video streaming) was not a useful predictor for self-perceived learner-to-teacher interaction. Although a number of studies have been conducted on interaction and synchronous systems, few studies analyzed the four types of interaction in the virtual classroom. Of these studies, none has examined this from the student and instructor perspective.

\section{Online Interaction Analysis Models}

A number of interaction analysis models have been developed to account for different aspects of interaction. Most of these models have been developed to analyze interaction in asynchronous communication. Henri (1992) developed a model for content analysis which included five dimensions (participation, social, interactivity, cognitive skills, and metacognitive knowledge and skills). Gunawardena, Lowe, and Anderson (1997) developed an interaction analysis model to examine meaning negotiation and co-construction of knowledge. Their model contained five progressive phases of knowledge co-construction which included sharing and comparing of information, discovery of dissonance, negotiation of meaning/co-construction of knowledge, testing and modification of proposed synthesis, and agreement/application of newly constructed meaning. Veldhuis-Diermanse (2002) and Lockhorst, Admiraal, Pilot, and Veen (2003) focused their interaction models on a constructivist framework. Veldhuis-Diermanse's method consists of three steps: 1) analyzing the participation and interaction; 2) focusing on different learning activities; and 3) focusing on the quality of constructed knowledge, which is based on the structure of the observed learning outcome. Lockhorst et al. (2003) focus on online cooperation, specifically on the learning strategies leading to in-depth levels of information exchange. DeWever, Schellens, Valcke, and Van Keer (2006) reviewed the different content analysis schemes to analyze transcripts of online asynchronous discussion groups. They reviewed 14 different interaction analysis models, but all of them attempted to identify both cognitive and social features of online interaction.

Chou (2002) used Bales's (1950) interaction process analysis model to compare interaction patterns between synchronous and asynchronous communication. This model analyzes socioemotional and task interactions. Schullo's (2005) synchronous interaction analysis 
model had 57 different interaction elements and was specifically designed for synchronous virtual classroom interaction. It includes the option to review audio, text chat, and the use of other features in the virtual classroom and classify them into one of the six categories of interactions. The interactions are also classified as academic, social, or technical.

\section{Purpose of this Study}

As more and more instructors have begun to integrate synchronous communication in their online courses, seeing the need for immediacy, socioemotional interaction, and engagement (Chou, 2002), it is essential that we look at how the different types of interaction can be promoted using the synchronous virtual classroom. It is important that all the types of interaction (learner-learner, learner-instructor, learner-content, and learner-interface) occur so that they enhance academic, social, and technical communication.

The purpose of the study was to understand the interaction capability of the synchronous virtual classroom. The research questions that are answered are as follows:

1. What perceptions do students have about learner-learner, learner-instructor, learnercontent, and learner-interface interaction within the virtual classroom?

2. What strategies and tools can an instructor use to enhance learner-learner, learnerinstructor, learner-content, and learner-interface interaction in the virtual classroom?

\section{Methodology}

The study was conducted at a university in the southeastern United States. Instructors at this institution have been using a synchronous virtual classroom, Horizon Wimba, for the past five years. In this research, a multiple case study design was employed. Each course was considered a single case with similarities and differences explored across the cases (Schullo, 2005; Stake, 2006). This was considered a valuable method of answering the research questions due to our interest in the process rather than the outcome in this context (Merriam, 1998). Also, cross-case analysis can facilitate generalizations across cases and the development of sophisticated descriptions and explanations (Miles \& Huberman, 1994).

As in many case studies, various research methods were implemented (Stake, 2006; Yin, 2003). Open-ended surveys and an interview were used to obtain detailed accounts (Dillman, 1999; Kvale, 1996) of interaction in the virtual classroom from students and the instructor. The researchers also used archived course sessions to systematically review and describe the events and behaviors under investigation (Marshall \& Rossman, 1989; Schullo, 2005). Methodological triangulation (using more than one method to collect data) and theory triangulation (using more than one theoretical scheme to interpret the phenomenon) were used to validate the findings (Denzin, 2006; Stake, 2006; Yin, 2003).

\section{Survey on Interaction in the Synchronous Virtual Classrooms}

We surveyed graduate students in an instructional technology program about their interactions within the synchronous virtual classroom. In the spring and summer of 2010, an on- 
line survey was administered using SelectSurvey@). The survey included five demographic questions and four open-ended survey items. The interaction survey question was phrased as "Describe your learner-learner experience in the synchronous virtual classroom." An email with a hyperlink to the survey and a brief message about its purpose was sent to graduate students in three different courses (Computer Based Instruction, Evaluation, and Performance Improvement) taught by the same instructor. Twenty-three students received the email and 21 of them completed the survey, yielding a 91\% response rate. Table 1 presents the profile of the 21 survey participants.

Table 1

Survey Respondent Profile

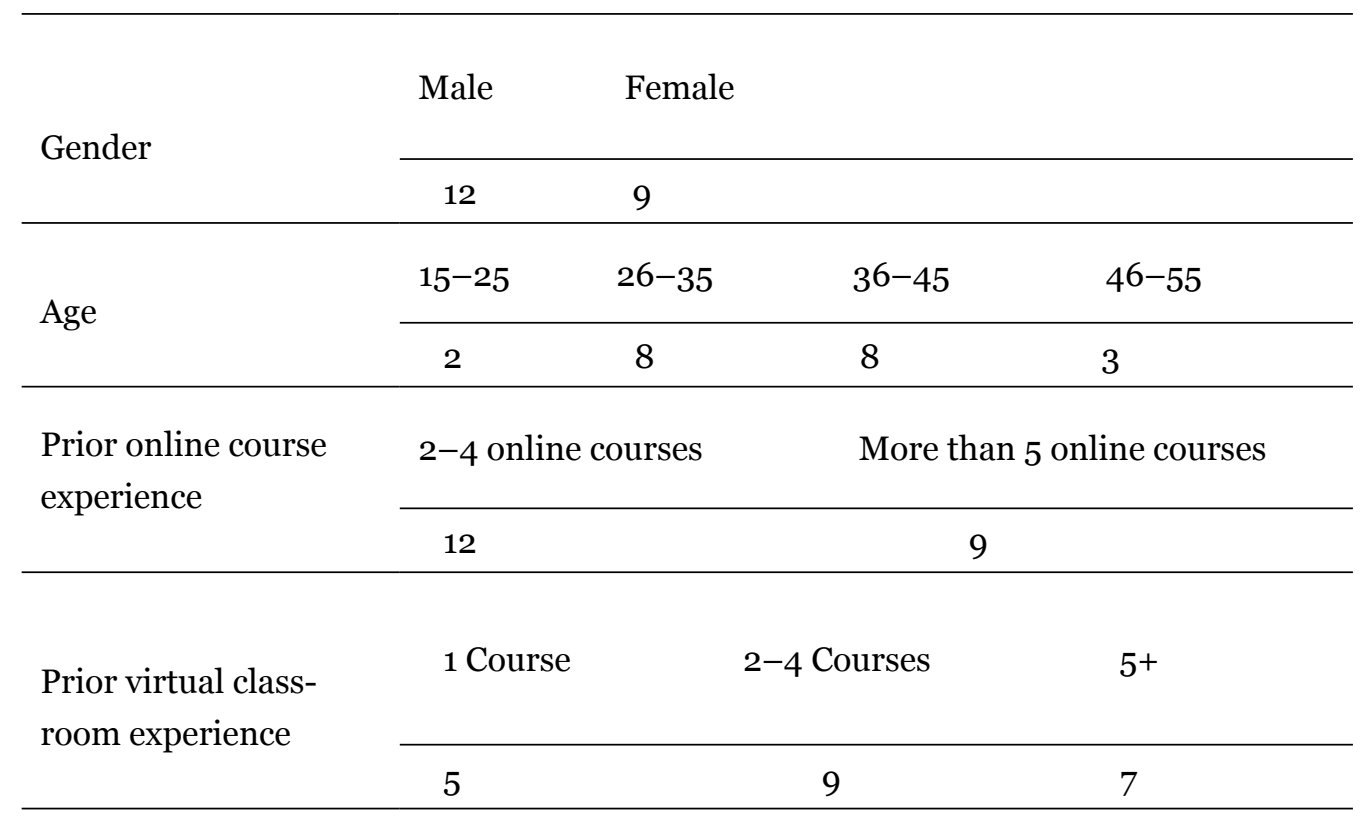

Thematic analysis was employed for the open-ended survey data. This involved grouping keywords into categories and identifying themes that emerged from the data.

\section{Instructor Interview}

The instructor who taught the three courses was interviewed to obtain the instructor's perspective on strategies and tools used to enhance interaction in the virtual classroom. The interview occurred at the university and lasted 30 minutes. The instructor was asked, "What strategies and tools do you use to enhance the four different types of interaction in the synchronous virtual classroom?”

\section{Course Archives}

Three archive sessions, one from each course, were randomly selected and analyzed to further our understanding of interactions that occurred in the virtual classroom. Course 1 was Computer Based Instruction, which met for three hours every Monday via the synchronous virtual classroom in the spring 2010 semester. Course 2 was an evaluation course which met for three hours every week on Thursday via the synchronous virtual classroom in the 
spring 2010 semester. Course 3 was Performance Improvement, and the class met for three hours on Tuesdays and Thursdays during summer session I in 2010. The class archives were saved on the Wimba server. The instructor who taught these classes emailed the links to the researcher, who analyzed the archives. The archival data were analysed using the instrument Schullo (2005) developed for measuring different types of interaction in the virtual classroom.

\section{Results}

The findings of the student survey, instructor interview, and archive analysis are presented in this order and across cases. For each method, the four types of interaction are used to organize the results.

\section{Surveys}

\section{Learner-instructor interaction.}

The participants were asked to describe their learner-instructor interaction experience within the virtual classroom. Six categories were identified to describe these experiences: interaction, instructor's teaching style, feedback, students as presenters, visual presence, and comparison with other delivery methods. Advantages were also grouped into a category.

Table 2

Student Responses to Learner-Instructor Interaction

\begin{tabular}{lll}
\hline Category & Quotation & $n$ \\
\hline
\end{tabular}

Interaction

Interaction is enhanced by text chat

Real time conversations

Private text chat

Instructor's teaching Direct instruction

style

Checked for understanding

Organized and Specific with expectations

In charge of discussion (in control) 
Feedback

Timely feedback

Prompts for feedback

Students as presenters

Visual presence

See the professor

Better than asynchronous

Similar to in person

Advantages

Instructor was accessible

5

Ask questions online than face to face

Fantastic

\section{Learner-learner interaction.}

The participants were asked to describe their learner-learner interaction experience within the virtual classroom. The categories that were formed were text chat, webcam, and audio. Advantages and disadvantages were also noted.

Table 3

Student Responses to Learner-Learner Interaction

\begin{tabular}{lll}
\hline Category & Quotation
\end{tabular}

Text chat

Creates strong interaction

Most occur in Chat room or discussion

I can choose who to send messages to

One on one chat/entire group chat

Webcam

Webcam makes it personal

Audio

Valuable to hear other student comments 
Disadvantages Dislike small groups (breakout rooms)

Email is problematic

Audio delays/talking at the same time as others

Advantages

Liked working with partners and groups

2

Very structured

\section{Learner-interface interaction.}

Twelve of the 19 students had positive commentary regarding the Horizon Wimba virtual classroom. 
Table 4

Student Responses to Learner-Interface Interaction

\begin{tabular}{|c|c|c|}
\hline Category & Quotation & $n$ \\
\hline \multirow[t]{3}{*}{ Positive/easy to use } & Positive & 13 \\
\hline & Wimba was fine & 4 \\
\hline & Easy to use & 6 \\
\hline \multirow[t]{12}{*}{ Disadvantages } & Occasionally malfunctions due to poor Internet connection & 19 \\
\hline & Clunky and cumbersome & \\
\hline & Frustrating not having multiple video feeds & \\
\hline & Had some problems getting my webcam work & \\
\hline & Wish the screen size was larger & \\
\hline & Dislike that you cannot use animation on PPT & \\
\hline & Dislike that you cannot click or copy paste weblinks & 2 \\
\hline & $\begin{array}{l}\text { Don't like that I get kicked off and cannot see the text chat from be- } \\
\text { fore when I sign in }\end{array}$ & 2 \\
\hline & $\begin{array}{l}\text { You have to interact deliberately (hand raising, clapping, or agree } \\
\text { icon) }\end{array}$ & \\
\hline & There is a learning curve & \\
\hline & Little uncomfortable & 2 \\
\hline & Difficult at first & \\
\hline \multirow[t]{5}{*}{ Advantages } & Interface works well & 5 \\
\hline & Enjoyed the experience having all my materials at home & \\
\hline & Surprised at the frequent interaction among partners and groups & \\
\hline & Loading PowerPoint did not take long & \\
\hline & No complaints & \\
\hline
\end{tabular}

\section{Learner-content interaction.}

This interaction describes the interaction between the learner and the material. The categories that were formed were as follows: PowerPoint, video, audio, weblinks, screenshare, 
advantages, and disadvantages.

Table 5

Student Responses to Learner-Content Interaction

\begin{tabular}{|c|c|c|}
\hline Category & Quotation & $n$ \\
\hline \multirow[t]{6}{*}{ PowerPoint } & PowerPoints are useless & 7 \\
\hline & PowerPoint formats is limited & 2 \\
\hline & Too much info on slides is distracting & \\
\hline & $\begin{array}{l}\text { Hard to follow a presentation while nonsensical text chatting } \\
\text { occurs }\end{array}$ & \\
\hline & Images are too small to see & \\
\hline & Able to show PowerPoint slides & \\
\hline \multirow[t]{3}{*}{ Audio } & Audio isn't always clear & 5 \\
\hline & Difficult to hold talk button while clicking through slideshow & \\
\hline & Audio, text, and images were clear and understandable & \\
\hline \multirow[t]{3}{*}{ Video } & Video doesn't seem to be possible & 3 \\
\hline & And view videos in Wimba & \\
\hline & Nice to see videos used & \\
\hline \multirow[t]{2}{*}{ Weblinks } & $\begin{array}{l}\text { Disliked that I cannot click or copy weblinks-waste learning } \\
\text { time }\end{array}$ & 4 \\
\hline & Nice to be able to click on links on chat window & \\
\hline Screenshare & $\begin{array}{l}\text { Screenshare feature was very slow and caused viewer to miss } \\
\text { interactive or dynamic content }\end{array}$ & 1 \\
\hline
\end{tabular}


Advantages

Disadvantages
Interesting to use features that are available

4

Excellent 24 hour access

Archive-you can revisit the class and see the entire environ-

ment including chat

Material is very accessible

I don't feel that I engage with the content as learning occurs 1 in the conversation

Overall, students were positive about the opportunity to interact with the instructor and classmates in real time using the virtual classroom. They liked the immediate feedback from the instructor and public and private chat options to interact, the screenshare features, the videos, and the ability to watch the archives. However, students disliked the technical problems due to Internet malfunction, occasional difficulty operating their microphone and cameras, not having multiple video feeds, being unable to see animations embedded in PowerPoint, and the inability to have clickable links on the eboard or via PowerPoint. Some students disliked the breakout rooms that were used to facilitate conversations among members of the same group.

\section{Instructor Interview}

The instructor who taught the three different courses was interviewed by one of the researchers. Table 7 includes quotations from the instructor.

Table 6

Select Quotations from the Instructor about Strategies and Tools that were Used to Facilitate the Four Types of Interaction

Interaction type $\quad$ Strategies and tools used

Learner-Learner

I send them into breakout rooms and create collaborative activities to engage in conversation. I then bring them back \& have them summarize their discussion. The other strategy I use is when I ask questions, I ask everyone to respond on the text chat so all others can see the responses too. Some students even use emoticons while talking to others; they also use both public \& private chat. They also have video enabled while talking so they can see each other. Some learners have been calling in using the phone to join the room when they cannot login using a computer. 
Learner-Instructor

Learner-Content

Learner-Interface
I let the students ask questions to clarify something. They can raise their hand, or type in text chat. They use audio, text, and video chat to talk to me. I do different activities, where they have to respond using text chat or audio chat or polling. I also do a lot of demonstrations using application share, and students interact with me, especially if they don't understand what I am showing them. I ask them to use the step-away feature so I can see if they are out, especially during breaks.

I have a PowerPoint every time I teach using the virtual classroom. I load this to the eboard. This helps me to get them to focus their attention to the content. I also take them on web tours, or share web links. To introduce them to other content on the web. Again, for the development courses, I demonstrate the tools using application sharing. The different practice activities help them with the content too. I give them group activities, which gets them to interact with content and other learners. I think there is a lot of learning happening in the virtual classroom just from interacting via text chat with other classmates. I also use audio chat all the time to explain the content.

I use the different features of the virtual classroom to enhance learner-interface interaction. I use the eboard, application sharing, all three types of chat - audio video \& text, hand raising, polling, break out rooms, step away feature, sharing we blinks, emoticons. I give a chance for students to present using the eboard; this gives them a chance to interact with the system and I provide feedback on their presentation.

\section{Archival Analysis of Classroom Interaction}

Schullo's (2005) instrument with 57 items on different interaction elements in the virtual classroom was used to analyze three archived sessions. One researcher reviewed audio, text chat, and use of other features in the virtual classroom in order to classify six categories of interactions. The interactions were also classified as academic, social, or technical. Interactions related to the course content were considered academic, interactions that related to the virtual classroom system were technical (e.g., audio issues, how to use a feature), and interactions that were not academic or technical were considered social. The archive from the third course, Human Performance Improvement, was the most interactive course with 705 interactions. Among the three courses, there were 815 total academic interactions, 352 total technical interactions, and 143 total social interactions.

This data revealed that most of the interactions were academic in nature; however, there were also a number of interactions related to technical issues and fewer social interactions. The archive analysis illuminated the different strategies and tools that were used to enhance interaction in the synchronous virtual classroom. Text chat, the microphone, and the hand-raising tool were used most often. Text chat was employed in various interactions, 
and academically related interactions were well supported by this tool.

\section{Course 1 - Computer Based Instruction (CBI)}

This class contained nine students, and the class session consisted of roughly 50 minutes of student presentations using PowerPoint within the virtual classroom. This was followed by lecture and 10 minutes for small group discussions in the breakout rooms. Students returned to the main room and reported on their discussions. During breakout sessions, the researcher was unable to track interactions. The webcam was on the professor during the entire class time. There was a lot of conversation in the chat room, and the researcher states that the level of learner-learner interaction was probably higher in the text chat than audio chat. Questions about the course content were addressed within the chat room without interrupting the lecture. There were lots of learner-learner and learner-instructor comments throughout the lecture. Everything was on topic or social in nature. The researcher was unable to examine the "step away" feature or the interactions in the breakout room because they are not archived. In the instructor-interface category, the microphone and application share feature were used the entire time.

\section{Course 2 - Evaluation and Change Management}

This class consisted of seven students. The instructor started the virtual classroom session by reviewing the learning objectives and checking with students regarding the status of their projects. The remaining time was used for lecture and students' response to readings. The last five to seven minutes were about the upcoming class and the necessary software. The instructor used lots of rhetorical questions such as "right?" or "yes?" Students seemed comfortable speaking even though they often paused. The instructor responded directly to each student who posed a question.

\section{Course 3 - Human Performance Improvement (HPI)}

This class had more interactions and more students (17) than the other two courses. Many of the students knew each other, which seemed to encourage more text chatting. This virtual classroom session was discussion focused. The instructor gave each student time to respond to the topic, and there was minimal lecture. The instructor affirmed student responses by nodding, which was visible via the webcam. In the instructor-interface category, the video and microphone were turned on the entire time. 
Table 7

Archival Analysis of Interaction within Three Instructional Technology Courses

\begin{tabular}{|c|c|c|c|c|c|c|c|c|}
\hline \multicolumn{2}{|c|}{ Course 1} & \multicolumn{3}{|c|}{ Course 2} & \multicolumn{4}{|c|}{ Course 3} \\
\hline CBI & & & Eva & ion & & HPI & & \\
\hline 范 & $\begin{array}{l}\text {. } \\
\text {. } \\
\text { ఝ }\end{array}$ & 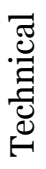 & 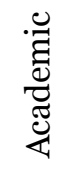 & 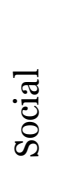 & 预 & 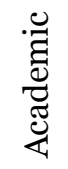 & $\begin{array}{l}\text {.శ్తే } \\
\text { ఝ } \\
\text { S }\end{array}$ & 串 \\
\hline
\end{tabular}

Directly observable instructor-learner interaction

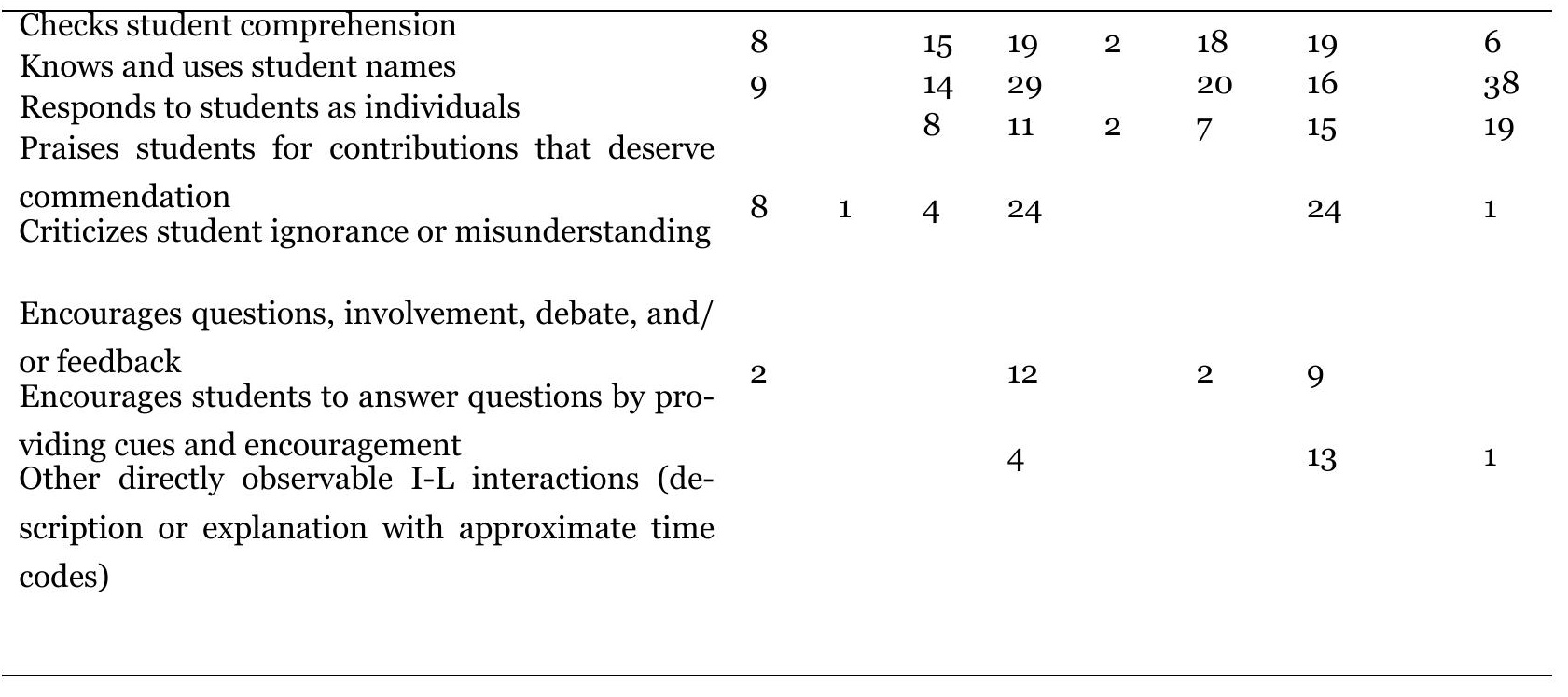

Directly observable learner-instructor interaction

\begin{tabular}{|c|c|c|c|c|c|c|c|c|}
\hline $\begin{array}{l}\text { Students ask questions of the instructor } \\
\text { Students volunteer information }\end{array}$ & 1 & 1 & 4 & 5 & 4 & 6 & 1 & 9 \\
\hline Students present information & & & & 1 & & 4 & & \\
\hline Student feedback is on topic & 12 & 1 & 1 & $\begin{array}{l}17 \\
18\end{array}$ & 6 & 63 & & 5 \\
\hline
\end{tabular}

Directly observable learner-content interaction

\section{Reading}

Writing (i.e., on whiteboard, in chat, etc.)

Presentation (i.e., verbal, graphical, etc.)

Discussion

Responds

Participates in poll

Other directly observable L-C interactions

\section{4}

Directly observable learner-learner interaction 


\begin{tabular}{|c|c|c|c|c|c|c|c|c|}
\hline \multicolumn{2}{|c|}{ Course 1} & \multicolumn{3}{|c|}{ Course 2} & \multicolumn{4}{|c|}{ Course 3} \\
\hline $\mathrm{CBI}$ & & & Eva & tion & & HPI & & \\
\hline 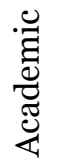 & 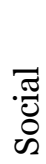 & 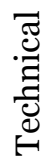 & 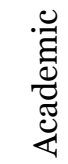 & $\begin{array}{l}\text {.స్త్ర } \\
\text { \& }\end{array}$ & 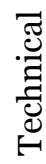 & 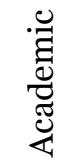 & 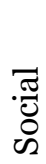 & 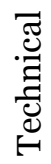 \\
\hline
\end{tabular}

Students discuss the content of the session with each other (on-task academic conversation)

Students engage in conversation that is not re$\begin{array}{llllll}13 & 13 & 3 & 8 & 4 & 36\end{array}$ lated to the subject of the session but is related to the course or other courses (off-task academic conversation)
Students engage in conversation that is not related to the course (social conversation) Students encourage other students' questions, involvement, debate, and/or feedback Students criticize other students' ignorance or misunderstanding Students use each other's names Other directly observable L-L interactions

Directly observable learner-interface interaction

\begin{tabular}{|c|c|c|c|c|c|c|c|c|c|}
\hline \multicolumn{10}{|l|}{ Work on eboard } \\
\hline Use microphone & 26 & 2 & 2 & 19 & & 5 & 39 & & 13 \\
\hline Exchange messages in text chat & 36 & 23 & 38 & 24 & 4 & 20 & 152 & 82 & 52 \\
\hline Raises hand & 2 & 1 & 2 & 1 & & & 8 & & \\
\hline Completes a poll & & & & 1 & & & & & \\
\hline Uses emoticons & & & & & & & & & \\
\hline Troubles connecting & & & & & & & & & \\
\hline Unable to use tools (specify) & & & & & & $\mathrm{Mic}^{*}$ & & & \\
\hline Use video & & & & & & & 28 & & \\
\hline Uses app sharing & 8 & & & & & & & & \\
\hline Joins breakout rooms & 6 & & & & & & & & \\
\hline Uses step away feature & & & & & & & & & \\
\hline Sharing weblinks & & & & & & & & & \\
\hline Uses the phone to join the room & & & & & & & & & \\
\hline Other directly observable L-I interactions & & & & & & & & & \\
\hline
\end{tabular}

Directly observable instructor-interface interac-

tion

Work on eboard

Use microphone

Exchange messages in chat

Ask students to raise their hands

Ask students to respond to polling 3

Troubles connecting

Use video 


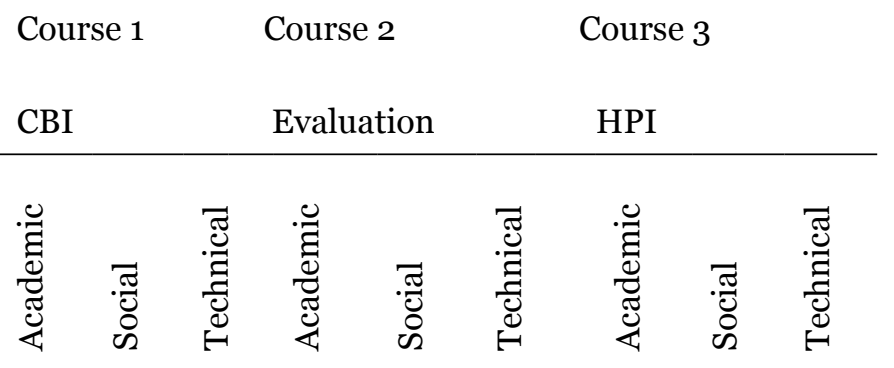

Uses app sharing

Creates breakout rooms

Uses step away feature

Sharing weblinks

Archives

Sets up guest access

Unable to use tools (specify)

Other directly observable instructor-interface in-

teractions

Total interactions
1

2

$\begin{array}{llllll}146 & 42 & 99 & 214 & 16 & 88\end{array}$

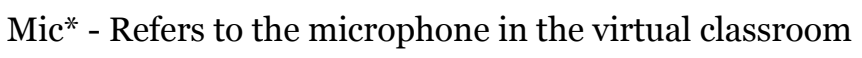

\section{Discussion}

Looking across the findings from each method (survey, interview, and archival analysis), the discussion focuses on the various forms of interaction within the virtual classroom. More specifically, the discussion addresses (a) students' perceptions of learner-learner, learner-instructor, learner-content, and learner-interface interaction within the virtual classroom; and (b) the strategies and tools that instructors use to enhance these forms of interaction within the virtual classroom.

Students agreed that the virtual classroom tool aided interaction in the different interaction categories. Dirckinck-Holmfield, Sorenson, Ryberg, and Buus (2004) and Arbaugh (2000) highlight the importance of designing virtual communities to enable different patterns and types of interaction. Instructors can act as facilitators and provide support, feedback, and guidance during live interaction (Khan, 2000). Bernard et al. (2009) suggest that increasing the quality of interactions in terms of cognitive engagement and meaningfulness might be of greater importance than increasing the quantity of interactions. Limiting the problems due to learner-interface interaction and enhancing the combination of learnerinstructor, learner-learner, and learner-content interactions will result in successful online learning (Schullo, 2005).

\section{Learner-Instructor Interaction}

In the current study, students mentioned that the instructor's teaching style (e.g., direct instruction, moderated discussions) and the different interaction methods (e.g., audio, text chat) played important roles in the learner-instructor interaction. The instructor had specific expectations and checked for understanding, which seemed to enhance learnerinstructor interaction in the synchronous virtual classroom. Participants said the following 
about the virtual classroom: a) that it helped them receive immediate feedback, b) that the presenter rights made the virtual experience better, c) that the visual presence of the instructor was beneficial, and (d) that they considered the experience positive overall. Chen, Ko, Kinshuk, and Lin (2005) demonstrated that the most promising aspect of the synchronous classroom is the provision of immediate feedback, which allows the participants to correct themselves immediately and strengthen their learning. The low-quality audio/video makes interaction difficult in a virtual classroom (Anderson, Beavers, VanDeGrift, \& Videon, 2003). Nevertheless, participants preferred viewing the live video to a prerecorded video of the instructor. The instructor in this study used the breakout rooms and text chat area as the major feature to enhance learner-learner interaction. While studies have found breakout rooms to be effective, they also found audio with video to be more effective in enhancing learner-learner interaction (Baker, 2002).

The archive analysis revealed that learners were able to express ideas or ask questions through text chat to the instructor without interrupting another speaker. The text chat tool provided a much-needed way to communicate technical difficulties when they arose, especially as other tools (such as the microphone) presented technical difficulties for the user. The microphone was frequently used during learner-instructor interactions. These interactions consisted of academic and technical topics but were rarely used for social interactions.

The instructor-learner interactions employed the microphone tool the most. Both the handraising and polling tools provided an organized method of interaction. The hand-raising tool was employed by the instructor for organizing class discussion, offering an effective way to ensure that all students' ideas, questions, and concerns were addressed.

\section{Learner-Learner Interaction}

Scholl, McCarthy, and Harr (2006) discovered that chat has advantages in informal communication when used in conjunction with the webcam. Seeing the students through the webcam made the learner-learner interaction more personal. Text chat seemed to promote the most learner-learner interaction in the synchronous virtual classroom. The students perceived both private chat and group communication as beneficial to all the students. Breakout rooms provided another vehicle for small group communication. Text chat helped overcome the audio delays and prevented students from talking at the same time during audio communication. Listening to other classmates and hearing their comments were valuable factors in the learner-learner interaction. Chou (2002) reported that synchronous message exchanges encouraged more socioemotional interactions. Linebarger, Scholand, Ehlen, and Procopio (2005) found that synchronous collaboration improved the formation of common mental models in terms of both time and quality. This idea was evidenced in this study as students were able to benefit from interacting with their peers in the breakout rooms. A virtual classroom increases interaction among students because it motivates learners and helps them develop positive attitudes towards the course (Aydin, 2008). According to the instructor, the majority of the learner-instructor interaction occurred through the three types of chat (audio, video, and text), and through application sharing, which was primarily used for demonstration. 
The archive analysis revealed that when learners had questions, other learners frequently chimed in with their thoughts and answers. This greatly enhanced the learning experience and supported learner-learner learning. Learners were able to present their work and participate in group sessions using the microphone. This tool was often used in combination with the text chat, which provided a seemingly effective method for learner-learner interaction. When the class format contained large amounts of lecture, many of the learner-learner interaction tools were used infrequently; whereas, learner-learner interactions increased with class discussions and when students presented course material.

\section{Learner-Interface Interaction}

Some students mentioned the initial learning curve when using the tool. Overall, the virtual classroom interface was considered easy to use, and it facilitated frequent interaction among the students. Ease of use seems to be a key feature in the adoption of this technology by both faculty and students (DuFrene, Lehman, Kellermanns, \& Pearson, 2009; Lehner, Nösekabel, \& Lehmann, 2003; Schullo, 2005; Van Raaij \& Schepers, 2008). Students indicated three disadvantages of the virtual classroom, which are the lack of multiple video feeds, the lack of animation capability when viewing a PowerPoint in the virtual classroom, and the inability to access Web sites from a PowerPoint. Similar to the findings of Thurmond and Wambach (2004), computer experience, perceptions about the technology being used, and access to technology were linked with learner-interface interactions. Wang's study (2004) indicated that desktop video conferencing also enhances oral-visual interaction. This study mentioned the importance of having a video feed in synchronous virtual sessions. According to the instructor, all features used to enhance the different types of interaction (eboard, application sharing, all three types of chat, audio, video, and text, hand raising, polling, breakout rooms, sharing weblinks, emoticons), enhance learner-interface interaction.

\section{Learner-Content Interaction}

Although students were engaged with the content and learning occurred through conversation, they described features that inhibited them from interacting with the content. For instance, the small-sized graphics were hard to see and content-related Web sites embedded in PowerPoints were inactive. Audio was unclear and the students did not like to hold the "talk" button while speaking. One way to solve this would have been to have the students raise their hands and give the opportunity for one person to speak at a time so that the speaker is audible. Students can also be instructed to use lock-talk, which frees them from having to hold the "talk" button while speaking. Students also noted that the video from the webcam was unclear and the screenshare was slow. The issues that the students described were directly related to the virtual classroom system that was used; whereas, other virtual classrooms have addressed some of these drawbacks by upgrading their interface. Despite the limitations with the virtual classroom that was used, the students listed features that helped them interact more with the content. For instance, they liked the ability to access the archive at any time, the ability to click on the weblinks from the chat room, and the text, audio, and video chat options. Finally, presenter control made the virtual classroom experience engaging for students. Presenter control provides students with access to the presen- 
tation tools, which enables them to present material to the class. This allowed the graduate students to take ownership of and responsibility for their learning. According to the instructor, the learner-content interaction primarily occurred through direct instruction by the use of PowerPoint, sharing weblinks, demonstrations through application sharing, and different chat options. This reinforces the view that sharing visuals and demonstrations along with the chat options enhances learner-context interaction.

\section{Best Practices}

Below is a list of best practices in conducting an interactive virtual classroom session.

\section{A. Before the Virtual Session}

- Send participants a reminder to run the wizard before the session.

- Provide the direct link to enter the virtual classroom (VC), especially for the first meeting if they are still unable to access the VC through the learning management system.

- Provide alternate phone numbers in case they are away from a computer and wish to connect to the class or have difficulty with audio.

- The above three steps will reduce the time the instructor has to spend on handling technical issues in the class.

\section{B. Introduction}

- Introduce yourself as the instructor for the session.

- Use a webcam if possible; if not, include a picture of yourself. Students prefer seeing the video instead of just hearing the instructor's voice.

- Set VC session rules regarding hand-raising as well as when and how to ask questions.

\section{Limiting Access/Guest Access}

- Provide only the access students need. (e.g., do not give eboard access unless they need it. Students love to draw on it during class.)

- The private chat option can be disabled if you do not see the need for it. Graduate students prefer to use the private chat option to talk to their classmates/teammates.

- Enable guest access if you plan on inviting guest speakers.

D. Features

- The text chat feature is very important as it provides feedback to the instructor regarding technical issues that can be resolved quickly with little disruption. 
- Text chat provides learner-learner and learner-instructor interactions for both social and content knowledge.

- Text chat provides immediate feedback for knowledge checks for learner-instructor interactions.

- The web camera provides a visual presence to instructor and students.

- Presenter control allows students to use their desktops to present and share their knowledge. This allows students to take ownership of and responsibility for their own learning as they must present their work.

- PowerPoint presentations used by the instructor are easily shared with the students through the eboard or content window and provide guidance for instructional flow.

- Share weblinks with the students in the course. PowerPoint slides are converted to images in Wimba. Therefore we recommend typing Web site links into the text chat area and/or sharing links via the Web site sharing feature.

- Breakout rooms facilitate small group discussion and increase learner-learner interaction as well as learner-content interaction.

\section{E. How to avoid audio and video delays?}

- Use an ethernet (network) connection always.

- Avoid using a wireless network connection. This could cause a delay in audio.

- As a presenter, you can see everyone's network statistics and help guide them in order to be successful.

- If a student complains about audio difficulty, do not wait for him/her to start the class. Tell him/her to watch the archive for the missed portion. A system reboot generally fixes these issues.

- Tell students not to run too many other applications when they are logged into the virtual classroom.

\section{F. Archiving}

- Remember to archive each session. It is very helpful for those who have missed class and also for the instructor in improving his/her teaching using VC.

- Archive accessibility provides students with the ability to review course content and a means for obtaining clarification about course content and/or assignments at a later date. 


\section{Limitations and Future Research}

This study was conducted with students in one graduate program in a specific region of the United States. The students were also instructional technology students and experienced virtual learners. The data were based on students' open-ended survey responses, which were short in nature and thus prevented us from using Schullo's (2005) framework for the analysis. Future research can use Schullo's (2005) framework for the various data collection modalities. We also suggest that researchers examine archival data for the same class multiple times and interview students to gain more in-depth responses. Additional suggestions include examining interaction in different types of courses (e.g., history, computer science), programs (e.g., higher education, curriculum, and instruction), settings (e.g., kinds of institutions), and subgroup (e.g., gender, age, race/ethnicity) in the virtual classroom. Based on these findings, instruction can be tailored to promote learning and student satisfaction in courses, programs, or institutions that use the virtual classroom.

\section{Implications}

Students perceived the virtual classroom as a means of enhancing learner-learner, learner-instructor, learner-content, and learner-interface interaction. The tools and strategies recommended by the students, instructor, and the archive analysis have implications for those who are considering teaching synchronously using the virtual classroom or adding synchronous components to asynchronous courses. The synchronous virtual classroom tools support authentic forms of interaction with reduced cost of travel and added flexibility. Instructors who use synchronous systems to teach are able to immediately address student understanding of the instructional concepts in an online setting. The best practices recommended in this study can help instructors conduct effective synchronous class sessions with enhanced interaction. This study recommends using different features such as text, audio, and video chat, polling, emoticons, application sharing, eboard, and breakout rooms to enhance interaction. The technical difficulties and disadvantages can be minimized by a) training the students ahead of time to use the applications, b) asking students to use the setup wizard before each class session, c) having students login ahead of time to help troubleshoot any potential technical difficulties, and d) providing a reference guide to address technical difficulties.

The virtual classroom tools are helpful in providing instant demonstration of hands-on skills such as learning an Adobe Photoshop application. These tools can also be adopted by faculty for office hours, where students can interact with the instructor remotely. Other implications for universities include using these synchronous systems to provide interactive professional development opportunities. Finally, this study has implications for distance education theory and research. 


\section{References}

Abdous, M., \& Yen, C. (2010). A predictive study of learner satisfaction and outcomes in faceto-face, satellite broadcast, and live video-streaming learning environments. Internet and Higher Education, 13(4), 248-257. doi:10.1016/j.iheduc.2010.04.005

Allen, E. I., \& Seaman, J. (2011). Going the distance: Online education in the United States 2011. Retrieved from http://www.onlinelearningsurvey.com/reports/goingthedistance.pdf

Ally, M. (2004). Foundations of educational theory for online learning. In T. Anderson \& F. Elloumi (Eds.), Theory and practice of online learning (pp. 3-31). Athabasca, AB: AU Press.

Anderson, R. J., Beavers, J., VanDeGrift, T., \& Videon, F. (2003). Videoconferencing and presentation support for synchronous distance learning. 33rd ASEE/IEEE Frontiers in Education Conference, Boulder, CO.

Anderson, T. (2003). Getting the mix right again: An updated and theoretical rationale for interaction. International Review of Research in Open and Distance Learning, 4(2), 1-14.

Anderson, T., \& Garrison, D. R. (1998). Learning in a networked world: New roles and responsibilities. In C. Gibson (Ed.), Distance learners in higher education (pp. 97-112). Madison, WI: Atwood Publishing.

Arbaugh, J. B. (2000). Virtual classroom characteristics and student satisfaction with online MBA courses. Journal of Management Education, 24(1), 32-54. doi:10.1177/105256290002400104

Aydin, B. (2008). An e-class application in a distance English language teacher training program (DELTT): Turkish learners' perceptions. Interactive Learning Environments, 16(2), 157-168. doi:10.1080/10494820701343900

Baker, G. (2002). The effects of synchronous collaborative technologies on decision making: A study of virtual teams. Information Resources Management Journal (IRMJ), 15(4), 79-93. doi:10.4018/irmj.2002100106

Bales, R. F. (1950). Interaction process analysis: A method for the study of small groups. Cambridge, MA: Addison-Wesley Press.

Bernard, R. M., Abrami, P. C., Borokhovski, E., Wade, C. A., Tamin, R. M., Surkes, M. A., $\&$ Bethel, E. C. (2009). A meta-analysis of three types of interaction treatments in distance education. Review of Education Research, 79(3), 1243-1289.

Cao, Q., Griffin, T. E., \& Bai, X. (2009). The importance of synchronous interaction for student satisfaction with course Web sites. Journal of Information Systems Edu- 
cation, 2O(3), 331-339.

Chen, N. S., Ko, H. C., Kinshuk, \& Lin, T. (2005). A model for synchronous learning using the internet. Innovations in Education and Teaching International, 42(2), 181-194.

Chou, C. (2002). A comparative content analysis of student interaction in synchronous and asynchronous learning networks. Proceedings of the 35th Hawaii International Conference on System Sciences, 5, 134.2. Retrieved from http://courseweb.stthomas.edu/ccchou/triennial/Publications/HICSS35.pdf

Coleman, S. (2012). Why do students learn online? Retrieved from http://www.worldwidelearn.com/education-articles/benefits-of-online-learning.htm

Daniel, J., \& Marquis, C. (1988). Interaction and independence: Getting the mix right. In D. Sewart, D. Keegan, \& B. Holmberg (Eds.), Distance education: International perspectives (pp. 339-359). London: Routledge.

Denzin, N. (2006). Sociological methods: A sourcebook (5th ed.). New Brunswick, NJ: Transaction.

DeWever, B., Schellens, T., Valcke, M., \& Van Keer, H. (2006). Content analysis schemes toanalyze transcripts of online asynchronous discussion groups: A review. Com puters \& Education, 46(1), 6-28.

Dillman, D. A. (1999). Mail and Internet surveys: The tailed design method. New York: John Wiley and Sons.

Dirckinck-Holmfield, L., Sorensen, E. K., Ryberg, T., \& Buus, L. (2004). A theoretical framework for designing online master communities of practice. In S. Banks et al. (Eds.), Networked learning (pp. 267-73). Lancaster, UK: University of Lancaster.

DuFrene, D. D., Lehman, C. M., Kellermanns, F. W., \& Pearson, R. A. (2009). Do business communication technology tools meet learner needs? Business Communication Quarterly, 72(2), 146-162.

Gilbert, L., \& Moore, D. R. (1998). Building interactivity into web courses: Tools for social and instructional interaction. Educational Technology, 38(3), 29-35.

Goussal, D. M., \& Udrízar Lezcano, M. S. (2003). Synchronous distance learning and virtual classrooms: A case study on student expectations and conditioning factors. Australian Journal of Educational Technology, 19(3), 388-404.

Gunawardena, C., Lowe, C., \& Anderson, T. (1997). Analysis of a global online debate and the development of an interaction analysis model for examining social construction of knowledge in computer conferencing. Journal of Educational Computing 
Research, 17(4), 397-431.

Henri, F. (1992). Computer conferencing and content analysis. In A. R. Kaye (Ed.), Collaborative learning through computer conferencing (pp. 117-136). Heidelberg: Springer..

Hillman, D. C. A, Willis, D. J., \& Gunawardena, C. N. (1994). Learner-interface interaction in distance education: An extension of contemporary models and strategies for practitioners. American Journal of Distance Education, 8(2), 30-42.

Hirumi, A., \& Bermudez, A. (1996). Interactivity, distance education, and instructional systems design converge on the information superhighway. Journal of Research on Computing in Education, 29(1), 1-16.

Hrastinski, S. (2006). Introducing an informal synchronous medium in a distance learning course: How is participation affected? The Internet and Higher Education, 9(2), $117-131$.

Kearsley, G. (1995, May). The nature and value of interaction in distance learning. Paper prepared for the Third Distance Education Research Symposium, University Park: Pennsylvania State University.

Kearsley, G. (1998). A guide to online education. Retrieved from http://home.sprynet. eom/ gkearsley/online.htm

Khan, B. H. (2000). Discussion of resources and attributes of the web for the creation of meaningful learning environments. CyberPyschology and Behavior, 3(1), 17-23.

Kvale, S. (1996). Interviews: An introduction to qualitative research interviewing. Thousand Oaks, CA: Sage.

LaPointe, D. K., \& Gunawardena, C. N. (2004). Developing, testing and refining of a model to understand the relationship between peer interaction and learning outcomes in computer-mediated conferencing. Distance Education, 25(1), 83-106. doi:10.1080/0158791042000212477

Lehner, F., Nösekabel, H., \& Lehmann, H. (2003). Wireless e-learning and communication environment. In Z. Maamar, W. Mansoor, and W.-J. van den Heuvel (Eds.), Proceedings of the Workshop at ISMIS 'O2, Lyon.

Linebarger, J. M., Scholand, A. J., Ehlen, M. A., \& Procopio, M. J. (2005). Benefits of synchronous collaboration support for an application-centered analysis team working on complex problems: A case study. Proceedings of the 2005 International ACM SIGGROUP Conference on Supporting Group Work, New York, NY, USA, pp. 51-6o. 
Lockhorst, D., Admiraal, W., Pilot, A., \& Veen, W. (2003). Analysis of electronic communication using 5 different perspectives. Paper presented at ORD 2003, Heerlen, Netherlands.

Mandernach, B. J. (2005). A faculty evaluation model for online instructors: Mentoring and evaluation in the online classroom. Online Journal of Distance Learning Administration, 8(3), 1-10.

Marshall, C., \& Rossman, G. B. (1989). Designing qualitative research. Newbury Park, CA: Sage.

Martyn, M. A. (2005). Using interaction in online discussion boards. Educause Quarterly, $4,61-62$.

McBrien, J. L., \& Jones, P. (2009). Virtual spaces: Employing a synchronous online classroom to facilitate student engagement in online learning. International Review of Research in Open and Distance Learning, 10(3). Retrieved from http://www. irrodl.org/index.php/irrodl/article/view/605/1264

Merriam, S. (1998). Qualitative research and case study applications in education. San Francisco: Jossey-Bass.

Miles, M. B., \& Huberman, A. M. (1994). An expanded sourcebook: Qualitative data analysis. Thousand Oaks, CA: Sage.

Miller, W. W., \& Webster, J. (1997, December). A comparison of interaction needs and performances of distance learners in synchronous and a synchronous classes. Paper presented at the American Vocational Association Convention, Las Vegas, NV.

Moore, M. J. (1993). Three types of interaction. In K. Harry, M. John, \& D. Keegan (Eds.), Distance education theory (pp. 19-24). New York: Routledge.

Motteram, G. (2001). The role of synchronous communication in fully distance education. Australian Journal of Educational Technology, 17(2), 131-149.

Northrup, P. (2001). A framework for designing interactivity into web-based instruction. Educational Technology, 41(2), 31-39.

Repman, J., Zinskie, C., \& Carlson, R. (2005). Effective use of CMC tools in interactive online learning. Computers in the Schools, 22(1-2), 57-69.

Roblyer, M., \& Ekhaml, L. (2000). How interactive are YOUR distance courses? A rubric for assessing interaction in distance learning. Online Journal of Distance Learning Administration. Retrieved from http://www.westga.edu/distance/roblyer32.html

Park, Y. J., \& Bonk, C. J. (2007). Is life a breeze?: A case study for promoting synchronous learning in a blended graduate course. Journal of Online Learning and Teaching, 
3(3), 307-323.

Pittinsky, M., \& Chase, B. (2000). Quality on the line: Benchmarks for success in internetbased distance education. Washington, DC: Institute for Higher Education Policy.

Scholl, J., McCarthy, J., \& Harr, R. (2006). A comparison of chat and audio in media richenvironments. In Proceedings of CSCW'o6. ACM Press, 323-332.

Schullo, S. (2005). An analysis of pedagogical strategies: Using synchronous web-based course systems in the online classroom (Unpublished dissertation). University of South Florida.

Shi, S. (2010). Teacher moderating and student engagement in synchronous computer conferences. Journal of Online Learning and Teaching, 6(2). Retrieved from http:// jolt.merlot.org/vol6no2/shi_o61o.htm

Stake, R. E. (2006). Multiple case study analysis. New York: Guilford Press.

Thurmond, V. A., \& Wambach, K. (2004). Understanding interactions in distance education: A review of the literature. International Journal of Instructional Technology and Distance Learning, 1(1). Retrieved from http://itdl.org/journal/Jan_04/ articleo2.htm

Van Raaij, E. M., \& Schepers, J. L. (2008). The acceptance and use of a virtual learning environment in China. Computers \& Education, 5o(3), 838-852.

Veldhuis-Diermanse, A. E. (2002). CSCLearning? Participation, learning activities and knowledge construction in computer-supported collaborative learning in higher education (Unpublished doctoral dissertation). Wageningen Universiteit, Nederland.

Verneil, M., \& Berge, Z. (2000). Going online: Guidelines for faculty in higher education. Educational Technology Review, 6(3), 13-18.

Wagner, E. D. (1994). In support of a functional definition of interaction. American Journal of Distance Education, 8(2), 6-29.

Wang, Y. (2004). Supporting synchronous distance language learning with desktop videoconferencing. Language Learning \& Technology, 8(3), 90-121.

Wimba (2011). Wimba Classroom 6.1. Retrieved online from http://www.wimba.com/ products/wimba_classroom/

Yin, R. K. (2003). Case study research: Design and methods. Thousand Oaks, CA: Sage. 


\section{Appendix}

\begin{tabular}{|c|c|c|c|c|}
\hline Reference & Research purpose & Context & $\begin{array}{l}\text { Data collection method \& } \\
\text { sample }\end{array}$ & Outcome \\
\hline $\begin{array}{l}\text { McBrien, J. L., \& Jones, P. } \\
\text { (2009). Virtual spaces: Em- } \\
\text { ploying a synchronous online } \\
\text { classroom to facilitate student } \\
\text { engagement in online learn- } \\
\text { ing. International Review of } \\
\text { Research in Open and Distance } \\
\text { Learning, 10(3). }\end{array}$ & $\begin{array}{l}\text { To analyze distance by explor- } \\
\text { ing the different elements of } \\
\text { Moore's (1993) transactional } \\
\text { distance theory, specifically } \\
\text { dialogue, structure, and learner } \\
\text { autonomy, through student re- } \\
\text { sponses to a survey about their } \\
\text { experience with the synchro- } \\
\text { nous online learning platform, } \\
\text { Elluminate Live! (E!). }\end{array}$ & $\begin{array}{l}\text { Three undergraduate and three } \\
\text { graduate courses in the Col- } \\
\text { lege of Education at a regional } \\
\text { campus of the University of } \\
\text { South Florida } \\
\text { Technology: Elluminate Live }\end{array}$ & $\begin{array}{l}\text { Short open-ended survey to } \\
\text { collect reflections } \\
35 \text { graduate and } 55 \text { undergrad- } \\
\text { uate students }\end{array}$ & $\begin{array}{l}\text { Particular themes emerged } \\
\text { related to dialogue, struc- } \\
\text { ture, and learner autonomy. } \\
\text { In addition, students rated } \\
\text { convenience, technical issues, } \\
\text { and pedagogical preferences } \\
\text { as important elements in their } \\
\text { learning experiences. }\end{array}$ \\
\hline $\begin{array}{l}\text { LaPointe, D. K., \& Gunawar- } \\
\text { dena, C. N. (2004). Developing, } \\
\text { testing and refining of a model } \\
\text { to understand the relation- } \\
\text { ship between peer interaction } \\
\text { and learning outcomes in } \\
\text { computer-mediated conferenc- } \\
\text { ing. Distance Education, 25(1), } \\
83-106 .\end{array}$ & $\begin{array}{l}\text { To develop and test a model of } \\
\text { the influences } \\
\text { impacting peer interaction in } \\
\text { an online course and determine } \\
\text { the relationship, } \\
\text { if any, between peer interaction } \\
\text { and learning outcomes }\end{array}$ & $\begin{array}{l}\text { Data collection was from } 6 \\
\text { colleges and Universities in the } \\
\text { US and } 1 \text { in Canada. } \\
\text { Technology: Computer-Mediat- } \\
\text { ed Conferencing }\end{array}$ & $\begin{array}{l}\text { Two online questionnaires } \\
228 \text { Community College and } \\
\text { University students enrolled in } \\
30 \text { online courses }\end{array}$ & $\begin{array}{l}\text { The results showed that } \\
\text { perceived teaching style had } \\
\text { a small direct effect }(0.23) \text { and } \\
\text { prior CMC experience had a } \\
\text { moderate direct effect }(0.31) \text { on } \\
\text { self-reported peer interaction; } \\
\text { self-reported peer interaction } \\
\text { had a strong direct effect }(0.66) \\
\text { on self-reported learning out- } \\
\text { comes peer interaction. }\end{array}$ \\
\hline
\end{tabular}




\begin{tabular}{|l|l|l|l|l|}
\hline Reference & Research purpose & Context & $\begin{array}{l}\text { Data collection method \& } \\
\text { sample }\end{array}$ & Outcome \\
\hline $\begin{array}{l}\text { Shi, S. (2010). Teacher moderat- } \\
\text { ing and student engagement } \\
\text { in synchronous computer } \\
\text { conferences. Journal of Online } \\
\text { Learning and Teaching, 6(2). }\end{array}$ & $\begin{array}{l}\text { To investigate the relationship } \\
\text { between and among teacher } \\
\text { moderating variables and } \\
\text { student engagement variables. } \\
\text { Student engagement consists } \\
\text { of three different aspects: } \\
\text { behavioral engagement, social- } \\
\text { emotional engagement, and } \\
\text { intellectual engagement. }\end{array}$ & $\begin{array}{l}\text { The study was conducted in an } \\
\text { online, three-credit university } \\
\text { level undergraduate course } \\
\text { that was delivered in real time } \\
\text { in a fall semester that con- } \\
\text { sisted of eleven consecutive } \\
\text { three-hour weekly sessions. }\end{array}$ & Rubrics & $\begin{array}{l}\text { Statistical results showed that } \\
\text { the number of teacher post- } \\
\text { ings had a significant effect on } \\
\text { student behavioral engagement } \\
\text { while the quality of teacher } \\
\text { moderating levels did not. } \\
\text { Student participation had a } \\
\text { significant effect on student } \\
\text { intellectual engagement, but } \\
\text { student attending or student } \\
\text { social-emotional engagement } \\
\text { did not. Finally, analyses } \\
\text { showed that both the number } \\
\text { of teacher postings and the } \\
\text { quality of teacher moderating } \\
\text { levels had a significant effect } \\
\text { on student intellectual engage- } \\
\text { ment. }\end{array}$ \\
\hline
\end{tabular}




\begin{tabular}{|c|c|c|c|c|}
\hline Reference & Research purpose & Context & $\begin{array}{l}\text { Data collection method \& } \\
\text { sample }\end{array}$ & Outcome \\
\hline $\begin{array}{l}\text { Aydin, B. (2008). An e-class ap- } \\
\text { plication in a Distance English } \\
\text { Language Teacher Training } \\
\text { program (DELTT): Turkish } \\
\text { learners' perceptions. Interac- } \\
\text { tive Learning Environments, } \\
\text { 16(2), 157-168. }\end{array}$ & $\begin{array}{l}\text { To investigate perceptions of } \\
\text { the students participating in } \\
\text { the electronic reading class } \\
\text { and explore whether or not the } \\
\text { e-class application had any im- } \\
\text { pact on the academic success } \\
\text { of learners. }\end{array}$ & $\begin{array}{l}\text { At Anadolu University, Eskise- } \\
\text { hir, Turkey in the 2000-2001 } \\
\text { academic year } \\
\text { E-class applications were used } \\
\text { to meet the increasing demand } \\
\text { for English language teachers } \\
\text { in the country. } \\
\text { Technology: Not specified }\end{array}$ & $\begin{array}{l}\text { Document analysis } \\
1 \text { group of } 26 \text { groups com- } \\
\text { posed of undergraduates were } \\
\text { randomly selected to partici- } \\
\text { pate. } 1 \text { group was exposed to } \\
\text { e-class while other students } \\
\text { had traditional instruction. }\end{array}$ & $\begin{array}{l}\text { Turkish adult learners mainly } \\
\text { have positive attitudes } \\
\text { towards e-class application. } \\
\text { This positive attitude might } \\
\text { be perceived as their willing- } \\
\text { ness and readiness for the } \\
\text { inclusion of technology into } \\
\text { language education. The } \\
\text { participants also appreciated } \\
\text { the idea of group work on the } \\
\text { computer. An e-class project } \\
\text { might therefore be suggested } \\
\text { as a way of increasing interac- } \\
\text { tion among students, because } \\
\text { such an application motivates } \\
\text { learners and encourages them } \\
\text { to develop positive attitudes } \\
\text { towards the course. Students } \\
\text { participating in this study also } \\
\text { reported that the e-class ap- } \\
\text { plication helped them prepare } \\
\text { for the later online part of their } \\
\text { education. }\end{array}$ \\
\hline
\end{tabular}




\begin{tabular}{|c|c|c|c|c|}
\hline Reference & Research purpose & Context & $\begin{array}{l}\text { Data collection method \& } \\
\text { sample }\end{array}$ & Outcome \\
\hline $\begin{array}{l}\text { Wang, Y. (2004). Supporting } \\
\text { synchronous distance lan- } \\
\text { guage learning with desktop } \\
\text { videoconferencing. Language } \\
\text { Learning \& Technology, 8(3), } \\
\text { 90-121. }\end{array}$ & $\begin{array}{l}\text { To examine the potential of } \\
\text { Internet-based desktop video- } \\
\text { conferencing in facilitating oral } \\
\text { and visual interaction in DLE } \\
\text { through a formative evaluation } \\
\text { of one specific videoconferenc- } \\
\text { ing tool, NetMeeting }\end{array}$ & $\begin{array}{l}5 \text { video conferencing ses- } \\
\text { sions with each student. The } \\
\text { students had to complete vari- } \\
\text { ous tasks during each session } \\
\text { and were located throughout } \\
\text { Australia. } \\
\text { Technology: NetMeeting }\end{array}$ & $\begin{array}{l}\text { Observations, transcipt analy- } \\
\text { sis, survey, or student percep- } \\
\text { tions } \\
4 \text { partcipants }\end{array}$ & $\begin{array}{l}\text { Data strongly supporting the } \\
\text { use of videoconferencing in } \\
\text { DLE for the provision of oral- } \\
\text { visual interaction. The ease } \\
\text { of installation and use makes } \\
\text { NetMeeting a user-friendly } \\
\text { videoconferencing tool. While } \\
\text { acknowledging three major } \\
\text { constraints (Internet band- } \\
\text { width, latency, and the com- } \\
\text { puting power of the individual } \\
\text { PC) on the quality of a video- } \\
\text { conference, this research has } \\
\text { successfully confirmed the } \\
\text { capability of NetMeeting in pro- } \\
\text { viding reliable and acceptable } \\
\text { audio and video quality. }\end{array}$ \\
\hline $\begin{array}{l}\text { Hrastinski, S. (2006). Introduc- } \\
\text { ing an informal synchronous } \\
\text { medium in a distance learning } \\
\text { course: How is participation af- } \\
\text { fected? The Internet and Higher } \\
\text { Education, 9(2), 117-131. }\end{array}$ & $\begin{array}{l}\text { To evaluate the introduction } \\
\text { of an IM system and its effect } \\
\text { on participation in the course. } \\
\text { Moreover, students in the } \\
\text { course that adopted the IM } \\
\text { system were compared with } \\
\text { students in the other course. }\end{array}$ & $\begin{array}{l}\text { Business English Online } \\
\text { course. The course involves } \\
\text { group discussions, and contin- } \\
\text { uous assessment of individual } \\
\text { and group } \\
\text { work. } \\
\text { Technology: Not specified }\end{array}$ & $\begin{array}{l}\text { Two questionnaires and 1:1 } \\
\text { interviews with students } \\
28 \text { students }\end{array}$ & $\begin{array}{l}\text { The results of this compari- } \\
\text { son indicate that the degree } \\
\text { of participation was higher in } \\
\text { the class that did not use IM. } \\
\text { However, then the degree of } \\
\text { participation by students in the } \\
\text { second offering that adopted } \\
\text { the IM system was compared } \\
\text { with the degree for those that } \\
\text { did not adopt the system. The } \\
\text { results of this comparison } \\
\text { indicate that the degree of par- } \\
\text { ticipation was higher for those } \\
\text { that adopted the IM system. }\end{array}$ \\
\hline
\end{tabular}




\begin{tabular}{|c|c|c|c|c|}
\hline Reference & Research purpose & Context & $\begin{array}{l}\text { Data collection method \& } \\
\text { sample }\end{array}$ & Outcome \\
\hline $\begin{array}{l}\text { Abdous, M., \& Yen, C. (2010). } \\
\text { A predictive study of learner } \\
\text { satisfaction and outcomes in } \\
\text { face-to-face, satellite broad- } \\
\text { cast, and live video-streaming } \\
\text { learning environments. Internet } \\
\text { and Higher Education, 13(4), } \\
\text { 248-257. }\end{array}$ & $\begin{array}{l}\text { To explore the relation- } \\
\text { ship between self-perceived } \\
\text { learner-to-teacher interaction } \\
\text { and learning outcomes and } \\
\text { satisfaction across various } \\
\text { delivery modes (face-to-face, } \\
\text { satellite broadcasting, or live } \\
\text { video-streaming). }\end{array}$ & $\begin{array}{l}\text { Participants were recruited } \\
\text { from a public four-year } \\
\text { research university in the mid- } \\
\text { Atlantic region of the United } \\
\text { States. } \\
\text { Technology: Not specified. }\end{array}$ & $\begin{array}{l}\text { Online Survey } \\
496 \text { students enrolled in a } \\
\text { variety of courses }\end{array}$ & $\begin{array}{l}\text { Delivery mode was not a useful } \\
\text { predictor for self-perceived } \\
\text { learner-to-teacher interaction. } \\
\text { Self-perceived learner-to-teach- } \\
\text { er interaction could serve as a } \\
\text { predictor for student satisfac- } \\
\text { tion in courses similar. Overall, } \\
\text { computer skill could serve as a } \\
\text { predictor for student satisfac- } \\
\text { tion, but those two variables } \\
\text { were negatively related to each } \\
\text { other. Therefore, the increase } \\
\text { in the self-perceived learner- } \\
\text { to-teacher interaction score } \\
\text { would be accompanied by } \\
\text { the increased probabilities of } \\
\text { obtaining a better course final } \\
\text { grade. }\end{array}$ \\
\hline $\begin{array}{l}\text { Goussal, D. M., \& Udrízar } \\
\text { Lezcano, M. S. (2003). Syn- } \\
\text { chronous distance learning } \\
\text { and virtual classrooms: A case } \\
\text { study on student expectations } \\
\text { and conditioning factors. Aus- } \\
\text { tralian Journal of Educational } \\
\text { Technology, 19(3), 388-404. }\end{array}$ & $\begin{array}{l}\text { To identify students' percep- } \\
\text { tions about hypothetical imple- } \\
\text { mentations of DL systems, in } \\
\text { particular the use of synchro- } \\
\text { nous two-way transmission } \\
\text { and virtual classrooms in new } \\
\text { locations. }\end{array}$ & $\begin{array}{l}3 \text { regional campuses of el } \\
\text { Universidad Nacional del Nor- } \\
\text { deste, Argentina } \\
\text { Technology: Not specified. } \\
\text { Hypothetical situations }\end{array}$ & $\begin{array}{l}\text { Survey } \\
2629 \text { undergraduates }\end{array}$ & $\begin{array}{l}\text { Asked students about their } \\
\text { foreseeable motivation and } \\
\text { concentration to take classes } \\
\text { via distance learning, on ac- } \\
\text { count that DL, in the lack of } \\
\text { teachers' physical, face-to-face } \\
\text { contact and its associated } \\
\text { interaction level, requires more } \\
\text { in both. Almost } 60 \% \text { consid- } \\
\text { ered it as "Normal," another } \\
14 \% \text { as "High," } 14.7 \% \text { as "Fair," } \\
\text { and } 3.7 \% \text { as "Low." The great } \\
\text { majority preferred a " } 50-50 " \\
\text { share, with class time loads } \\
\text { up to } 10 \text { hours a week for each } \\
\text { delivery form (50.2\% for live } \\
\text { classes and 53.9\% for virtual, } \\
\text { synchronous 2-way full duplex } \\
\text { DL classes). }\end{array}$ \\
\hline
\end{tabular}




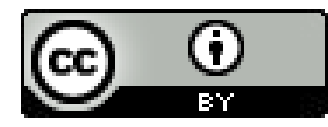

\section{Athabasca University $\mathbf{a}$}

